\title{
Stanistaw Obirek
}

\section{Zbyt wiele racji. \\ Uwagi na marginesie książek Normana G. Finkelsteina i Daniela J. Goldhagena*}

Czesław Miłosz swoją biografię intelektualną, będącą próbą wyjaśnienia - sobie i innym - okresu współpracy z komunistycznym rządem Polski Ludowej w latach 1946-1950, a zatytułowaną Zniewolony umyst, opatrzył wielce mówiącym cytatem, którego autorstwo przypisał staremu Żydowi z Podkarpacia: „Jeżeli dwóch kłóci się, a jeden ma rzetelnych 55 procent racji, to bardzo dobrze, i nie ma się co szarpać. A kto ma 60 procent racji? To ślicznie, to wielkie szczęście i niech Panu Bogu dziękuje! A co by powiedzieć o 75 procent racji? Mądrzy ludzie powiadają, że to bardzo podejrzane. No, a co o 100 procent? Taki, co mówi, że ma 100 procent racji, to paskudny gwałtownik, straszny rabuśnik, największy łajdak”2.

Lektura Zniewolonego umystu to zajęcie nader instruktywne. Dobrze się stało, że dotarł pod strzechy i stał się lekturą szkolną. Kiedyś zachwycił amerykańskiego mnicha Thomasa Mertona, który nawiązał niezwykle ciekawą korespondencję z jego autorem i był przekonany, że dzięki książce Miłosza zrozumiał mechanizmy totalitarnego zniewolenia. Merton nie był w swych odczuciach odosobniony, dla wielu jest to najlepsza diagnoza systemu totalitarnego. Zapewne jednym ze źródeł trafności spostrzeżeń Miłosza jest obrazowe i nader sugestywne credo poznawcze podkarpackiego Żyda. Nawet totalitarny system wymyka się jednoznacznym ocenom, a zbyt pochopne szafowanie ocenami może mieć nieobliczalne konsekwencje. Doświadczył tego zresztą sam Miłosz. Jego książka nie zadowoliła nikogo. Sam o tym wspomina w rozmowie z Włodzimierzem Boleckim dołączonej do wydania z 1999 roku w Wydawnictwie Literackim, pomyślanego właśnie jako lektura szkolna. Otóż Czesław Miłosz powiada, iż z jednej strony „Jeżeli były we Francji recenzje, to tylko negatywne, nazywające mnie sługusem imperializmu”, z drugiej zaś „Przez dziesięć lat Amerykanie odmawiali mi wizy jako podejrzanemu o kryptokomunizm”. O odbiorze w PRL nie ma potrzeby wspominać. Władza komunistyczna po prostu zakazała lektury, a autora skazała na niebyt.

* N. G. Finkelstein, Przedsiębiorstwo holokaust, Oficyna Wydawnicza Volumen, Warszawa 2001; D. J. Goldhagen, Niedokończony rozrachunek. Rola Kościoła katolickiego w Holocauście i niedopetniony obowiazek zadośćuczynienia, Sic!, Warszawa 2005.

${ }^{2}$ Cz. Miłosz, Zniewolony umyst, Wydawnictwo Literackie, Kraków 1999, motto poprzedzające tekst na nienumerowanej stronie. 
Recepcja książki Miłosza (podobnie zresztą jak jej treść) może stanowić pouczający punkt wyjścia do refleksji nad odbiorem książek o Holokauście, które w ostatnich latach obrodziły nader obficie, prowokując niekiedy bardzo gwałtowne debaty. Jak się wydaje, takie porównanie jest zasadne, Miłosz bowiem o Zagładzie napisał ważne wiersze jako jej świadek, a wymordowanie europejskich Żydów można traktować jako graniczny przypadek totalitarnych zachowań. W pierwszych dziesięcioleciach po Zagładzie fundamentalne opracowania historyków, socjologów, politologów, a nawet psychiatrów nie budziły zainteresowania szerszego odbiorcy. Dotyczy to zresztą nie tylko Polski czy krajów komunistycznych, w których Zagłada poddana została daleko idącej ideologizacji, również w Stanach Zjednoczonych, Izraelu i Europie Zachodniej był to temat objęty swoistą tabuizacją. Jest to problem, który w chwili obecnej jest przedmiotem bardzo intensywnego namysłu, a który niekiedy określa się walką o pamięć. Same analizy Holokaustu przeważnie stanowiły owoce zbiorowego i nader żmudnego namysłu nad tą największą tragedią ludzkości. Prawdopodobnie zbyt wielki był ciężar gatunkowy opisywanych doświadczeń, zbyt żywe wspomnienie tragedii, zbyt wielu świadków pamiętających wydarzenia, by można było pozwolić sobie na intelektualne harce i dowolności interpretacyjne. Zapewne nie bez znaczenia było poczucie bezradności i brak podstawowych pojęć, by nazwać wymykające się dotychczasowym kategoriom doświadczenie. Kilka lat temu ta sytuacja uległa radykalnej zmianie. Stało się to w dużym stopniu za sprawą dwóch nader błyskotliwych politologów amerykańskich Daniela Jonah Goldhagena (ur. 1959) i Normana G. Finkelsteina (ur. 1953), którzy jak się wydaje, bardziej są zainteresowani publiczną debatą na temat swoich książek i zawartych w nich tez niż samym wydarzeniem Holokaustu. Obaj należą do tzw. drugiego pokolenia (rodzice Finkelsteina przeżyli warszawskie getto i obozy koncentracyjne, ojciec Goldhagena pochodzi z Czerniowiec), obaj odnieśli znaczny sukces wydawniczy, obaj są przekonani, że mają 100 procent racji i dla obu każde odmienne zdanie jest źródłem coraz większej irytacji. Szczególnie nie znoszą siebie nawzajem. Ale obaj mają oddanych zwolenników, którzy podziwiają u swych bohaterów odwagę i bezkompromisowość $\mathrm{w}$ formułowaniu jasnych i zdecydowanych tez. Problem polega na tym, że owe tezy nie ułatwiają rozumienia problemu, o którym z takim zapałem rozprawiają. Obawiam się, że mamy do czynienia z procesem odwrotnym. Im więcej stronic zaczernia Daniel Jonah Goldhagen i Norman G. Finkelstein, tym trudniej dociec celu, jakiemu miałyby służyć ich publikacje i co tak naprawdę ,autor chce przez to powiedzieć". I na nic zdają się deklaracje obu autorów, iż głównym celem ich twórczości jest szukanie prawdy. Ja w każdym razie należę do grona sceptyków i spróbuję zdać sprawę z mego rosnącego pomieszania. Od razu muszę wyjaśnić, iż w obu przypadkach różne są źródła owego pomieszania.

A wszystko zaczęło się kilka lat temu, gdy w ramach zajęć poświęconych filozoficznym i teologicznym implikacjom Holokaustu zaproponowałem studentom lekturę książek obu tych autorów. U studentów wygrał zdecydowanie Finkelstein. Mnie bliższy był Goldhagen. Finkelstein podobał się studentom zapewne nie tylko z powodu ciętego języka i zwięzłości wywodu. Jego bezpardonowa krytyka „przemysłu holokaust” ma wszelkie pozory świętego gniewu, którym ogarnięty jest człowiek osobiście dotknięty i obrażony „malwersacjami domniemanych beneficjentów” Holokaustu. Ważny 
też był fakt, iż Finkelstein jako autor żydowski krytykował organizacje żydowskie. Lektura Goldhagena okazała się ponad siły studentów, jak mniemam, nie tylko ze względu na objętość. Nie tylko Gorliwi kaci Hitlera, ale i A Moral Reckoning (wtedy jeszcze nie tłumaczony) przerosły ich możliwości. Tezy politologa z Harvardu po prostu zupełnie nie przystawały do sposobu myślenia polskiego studenta. Oparte były na bibliografii niedostępnej $\mathrm{w}$ Polsce, a radykalny krytycyzm pod adresem papiestwa natrafiał na barierę bezkrytycznego podziwu dla dokonań Jana Pawła II, barierę, która okazała się nie do pokonania.

Polskie tłumaczenie, które ukazało się w kwietniu 2005 roku, również sprawia ogromne kłopoty, ale o tym za chwilę. Najpierw chcę poświęcić kilka uwag jego adwersarzowi.

Książka Normana Finkelsteina Przedsiębiorstwo holokaust to błyskotliwy esej, a właściwie paszkwil, do którego polski wydawca dołączył Posłowie do polskiego wydania, w którym Finkelstein zdaje sprawę z ostatnich „oszustw głównych przedstawicieli przedsiębiorstwa holokaust”, oraz Goldhagen dla początkujących, czyli „Sassiedzi” J. T. Grossa, w którym autor „rozprawił się” z książką Jana Tomasza Grossa - przypomnijmy, sprowokowała ona ogólnonarodową debatę na temat Holokaustu w Polsce. Jak łatwo się domyśleć, dla Finkelsteina Gross wpisał się w coraz lepiej prosperujące „przedsiębiorstwo holokaust”, a z polskiej debaty nie zrozumiał dosłownie nic.

O Normanie Finkelsteinie napisał znakomity artykuł Michał Głowiński, nadając mu wielce mówiący tytuł Nienawidzić siebie ${ }^{3}$. Nie jestem pewien, czy w samej rzeczy można „fenomen Finkelsteina” do końca wytłumaczyć za pomocą zagadkowego i w gruncie rzeczy psychiatrycznego pojęcia nienawiści siebie, jak to proponuje Głowiński, niewątpliwie jednak skutki jego „demaskatorskich” poczynań są doprawdy nieobliczalne. I tutaj przyznaję Michałowi Głowińskiemu rację już bez zastrzeżeń. Warto więc przywołać końcowe wnioski jego analiz: „Finkelstein nie tylko mówi to, czego skrajna nacjonalistyczna prawica chętnie słucha, mówi to, co ona głosi, posługuje się lansowanymi przez nią kategoriami, używa w ogromnej mierze jej języka. Po prostu tworzy wizję świata, która nie tylko jej odpowiada, ale po prostu nakłada się na to, co przedstawiciele ekstremalnej prawicy głoszą. Finkelstein przejmuje z dobrą wiarą i w jakiejś mierze zapewne nieświadomie różnego rodzaju antysemickie stereotypy. W tym dwa najważniejsze. Najpierw ten, według którego dla Żydów najważniejsze są pieniądze i one stoją za wszystkim, co czynią. To one właśnie są jedyną wartością. I dla ich zdobycia Żydzi skłonni są do najgorszych bezeceństw. Następnie stereotyp spisku żydowskiego, spisku ludzi, którzy wszelkiego rodzaju sposobami dążą do opanowania świata i w tym dążeniu pozbawieni są wszelkich skrupułów i moralnych zasad”4. Głowiński zwraca też uwagę na paradoksalny, a nawet przewrotny użytek, jaki z książki Finkelsteina czyni skrajna prawica, w tym również - a może zwłaszcza - prawica polska: „Jego książka dla skrajnej prawicy, niekiedy bliskiej rasizmowi, ma jeszcze jeden walor nie do pogardzenia: została napisana przez człowieka, który wprawdzie potępia społeczność żydowską i nie znajduje w niej jaśniejszego punktu, nie tai jednak swego żydowskiego

\footnotetext{
${ }^{3}$ M. Głowiński, Nienawidzić siebie, „Nauka” 2004, nr 3, s. 9-20.

${ }^{4}$ Ibidem, s. 19.
} 
pochodzenia. I to właśnie ma decydować o jego wiarygodności. Gdyby ta oskarżycielska kanonada sprokurowana została nie przez autora przyznającego się do swojego żydowskiego pochodzenia, ale jakiegoś innego, w polskim przypadku któregoś z producentów tego rodzaju makulatury w typie Henryka Pająka czy Jerzego Roberta Nowaka, przeszłaby pewnie niezauważona" ${ }^{5}$.

Pewnie tak. Tymczasem Finkelstein wciąż pisze i wciąż jest gorliwie tłumaczony na język polski. Jego następna książka Wielka hucpa wydana w 2006 roku została już opatrzona stosownym wstępem wziętego dziennikarza polskiego, by czytelnik polski nie przeoczył doniosłego znaczenia dzieła, które trzyma w ręku'. Tym razem celem ataku Normana Finkelsteina jest polityka Izraela i „jego amerykańscy poplecznicy”, zwłaszcza znany profesor prawa z Harvard University Alan M. Dershowitz, autor niezwykle popularnej w pewnych kręgach amerykańskich Żydów książki Chutzpah ${ }^{7}$, w której stara się przywrócić amerykańskim Żydom poczucie godności, w tym również nobilituje tytułowe pojęcie żydowskiej hucpy. Trzeba jednak od razu zaznaczyć, iż dla wielu Żydów jej autor jest rodzajem samozwańczego „reprezentanta interesów żydowskich”, który poprzez swoje działania i publikacje więcej tym interesom szkodzi, niż pomaga. Tytuł książki Dershowitza stał się też pretekstem do ironicznego zapożyczenia dla tytułu ostatniej książki Finkelsteina. Rzecz zasługuje na równie uważną lekturę, jak Przedsiębiorstwo holokaust, roi się bowiem w niej od cytatów i „demaskujących twierdzeń”, a wszystko w znanym nam już, nieznoszącym sprzeciwu i nieznającym wątpliwości stylu. I właśnie ten styl jest największym jej problemem. No bo przecież nikt o zdrowych zmysłach nie będzie negował potrzeby zwrócenia uwagi na konieczność gwarantowania i respektowania praw Palestyńczyków. Czynią to zresztą liczne organizacje legalnie działające na terenie Izraela, w tym obficie cytowana przez Finkelsteina Amnesty International czy B’Tselem (Izraelskie Centrum Informacji nt. Przestrzegania Praw Człowieka na Terytoriach Okupowanych). Podobnie problematyczne wydają się liczne publikacje wspomnianego Alana M. Dershowitza, który jest głównym celem ataków Finkelsteina, jednakże otwarte pozostaje pytanie, jaki jest sens publikowania żarliwych polemik, jeśli polski czytelnik nie ma dostępu do krytykowanych publikacji.

Dla mnie jednak głównym przedmiotem uwagi jest autor Gorliwych katów Hitlera, książki, która w Niemczech sprowokowała ogólnonarodową debatę, a w Polsce została skwitowana dość lakonicznym stwierdzeniem: „Ta książka nie odkrywa dla nas niczego nowego"9. Nie jestem tego pewien. Niezwykle emocjonalna i o ogólnonarodowym zasięgu debata w 2000 i w 2001 roku wokół książki Jana Tomasza Grossa Sąsiedzi ${ }^{10}$

${ }^{5}$ Ibidem.

${ }^{6}$ N. G. Finkelstein, Wielka hucpa. O pozorowaniu antysemityzmu i fatszowaniu historii, Chicago-Warszawa 2006.

${ }^{7}$ A. M. Dershowitz, Chutzpah, New York 1991.

${ }^{8}$ D. J. Goldhagen, Gorliwi kaci Hitlera. Zwyczajni Niemcy i Holokaust, Prószyński i S-ka, Warszawa 1999.

9 Tak napisała o niej „Rzeczpospolita” w numerze z 11 II 1999 w recenzji podpisanej inicjałami KM, a zatytułowanej „Porzadni” zbrodniarze.

10 J. T. Gross, Sąsiedzi, Wydawnictwo Pogranicze, Sejny 2000. 
zdaje się wskazywać coś zupełnie innego. Jeszcze wiele „nowych rzeczy” społeczeństwo polskie ma przed sobą, w tym również konfrontację z faktami tak drastycznymi, jak udział Polaków w pogromach na ludności żydowskiej w czasie Zagłady. Feliks Tych, omawiając zarówno książkę (wskazując również jej faktograficzne i metodologiczne mankamenty), jak i jej recepcję w Niemczech, stwierdził: „Książka ta przyniosła ze sobą przekroczenie kolejnego progu spraw okrytych milczeniem. Na wszystkich publicznych dyskusjach o niej obecna na sali młodzież niemiecka znacznie goręcej oklaskiwała wypowiedzi samego autora niż siedzących za tym samym stołem historyków niemieckich. Generacja wnuków w Niemczech jest już wolna od wszelkich obciążeń przeszłością i odpowiedzialnością za nią. I chce wiedzieć całą prawdę o pokoleniu swoich dziadków, niezależnie od tego, jak gorzka by ta prawda była"11.

Książka Goldhagena Niedokończony rozrachunek. Rola Kościoła katolickiego w Holocauście i niedopetniony obowiazek zadośćuczynienia spotkała się z dość radykalnym sprzeciwem, głównie w Stanach Zjednoczonych. Sam Goldhagen z nietajoną satysfakcją mówi o tym w posłowiu, które opatrzył znamiennym podtytułem Konfrontacja $z$ Kościotem. Autor swoją książkę określił jako „ambitny i poważny projekt intelektualny” (s. 311), który niestety, nie spotkał się z oczekiwaną odpowiedzią: „Zakrojona na szeroką skalę debata, która rozpoczęła się jesienią 2002 roku, potwierdziła moje trzy przypuszczenia. Kościół katolicki - sięgając do zapasu swoich politycznych forteli - z całej siły odpierał wezwanie do moralnego rozrachunku, sabotował poważną dyskusję na tematy moralne i usuwał z pola widzenia kwestie intelektualne” (s. 312). Dowiadujemy się więc, że Michael Novak, wpływowy konserwatywny teolog katolicki, nazwał go Wolterem, a Eugen Fischer, szczególnie zasłużony w dialogu chrześcijańsko-żydowskim, polecił mu wizytę u psychiatry. Reakcja Fischera jest zaskakująca, bo jest on człowiekiem znanym $z$ otwartości i dialogicznej postawy.

Lepiej wyglądała sprawa w Niemczech, gdzie w publicznych debatach nasz autor nieodmiennie odnosił sukcesy i wykazywał słabość, a nawet nieudolność swoich adwersarzy. Jak się wydaje, ulubioną bronią Goldhagena jest uprzedzanie możliwych zarzutów: „Myśleli też chyba [jego przeciwnicy - S. O.], że nikt nie zorientuje się, iż w książce stwierdzam wyraźnie, że nie jest ona wyczerpującym dziełem historycznym, lecz - począwszy od tytułu - rozprawą moralno-filozoficzną. Podkreślałem ponadto niejednokrotnie, że nie jestem historykiem, lecz politologiem, a moje rozważania mieszczą się w nurcie etyki stosowanej” (s. 315). Wydaje się, iż nie bez podstaw Goldhagen zarzuca swoim polemistom drobiazgowość w wytykaniu drobnych potknięć faktograficznych przy pomijaniu zasadniczego ostrza jego krytyki: „Najbardziej uderzające okazały się wypaczenia historii oraz treści mojej książki, do jakich posunęli się polemiści. Podczas kolejnych dyskusji panelowych wytykano mi: »nie wspomniał pan o tym« albo "napisał pan tak i tak, a to błąd«. Ale nawet przy tak nieuczciwej strategii apologeci Kościoła niewiele mieli do powiedzenia w sprawie zasadniczej” (s. 316). Nawet jeśli Goldhagen ma tylko 10 procent racji, to te dziesięć procent zasługuje na uwagę. Mimo wszystko, o ile mi wiadomo, Niedokończony rozrachunek nie powtórzył sukcesu

${ }^{11}$ F. Tych, Dtugi cień Zagłady. Szkice historyczne, Żydowski Instytut Historyczny, Warszawa 1999, s. 166. 
wydawniczego Gorliwych katów Hitlera w Niemczech. Zapewne jednym z powodów było to, iż tym razem na celowniku znalazł się tylko Kościół katolicki, a nie całe chrześcijaństwo i nie tylko Niemcy. Zabierali głos głównie hierarchowie katoliccy.

Można było oczekiwać, iż w katolickim kraju, takim jak Polska, książka stanie się wydarzeniem i rozpocznie, podobnie jak Sąsiedzi Grossa, ogólnonarodową debatę. A w każdym razie, że stanie się dla polskiego Kościoła katolickiego poważnym wezwaniem, skoro na jej kartach pojawia się równie często, jak kontrowersyjny papież czasów Zagłady Pius XII, nazwany przez Johna Cornwella „papieżem Hitlera”, polski papież Jan Paweł II. Nic z tego. Być może jednym z powodów był czas pojawienia się książki na polskim rynku - kwiecień 2005 roku, wszak wiadomo, co się wtedy wydarzyło. Nie tylko polski Kościół katolicki, ale całe społeczeństwo zamarło, a właściwie wsłuchiwało się w głos z Watykanu - coraz bardziej słabnący głos umierającego polskiego papieża. W takich okolicznościach trudno o debatę, a zwłaszcza o moralny rozrachunek instytucji, która za pontyfikatu Jana Pawła II osiągnęła niespotykany w dziejach autorytet. Od tamtego czasu minął rok i nic nie zapowiada zmian w rozumieniu przeszłości Kościoła. Jak się wydaje, dzieje się tak z ogromną szkodą dla wiarygodności jego misji ewangelizacyjnej. Właśnie o tym traktuje książka Daniela Goldhagena.

Do tej pory w Polsce jedynie dla „Nowych Książek” Niedokończony rozrachunek omówił ks. Michał Czajkowski, który wytknął jej autorowi dość zasadnicze błędy i nieuprawnione uogólnienia. Dopatrzył się w niej nawet pewnych podobieństw do pism... antysemickich: „Antykatolickość Goldhagena brzmi mi czasem swojsko: jakbym czytał jakiś pamflet antysemicki”. Nie odmawia jednak książce użyteczności: „Tytuł książki jest dla nas wezwaniem. Rzeczywiście nasz rozrachunek z przeszłością jest ciąle niedokończony - i jako święty Kościół grzesznych ludzi będziemy zawsze uznawali i wyznawali nasze winy [...]. Goldhagen podaje sporo nieznanych faktów i tekstów, często przejmujących i zawstydzających, próbuje wstrząsnąć sumieniami katolików”12. Chciałbym poniżej zaproponować lekturę Niedokończonego rozrachunku właśnie jako wstrząsu moralnego.

Bo tym właśnie ta książka jest - wielką mową oskarżycielską zbudowaną na schemacie nauczania krytykowanej instytucji. Głównym materiałem dowodowym jest niezgodność życia katolików (zarówno hierarchii z papieżem włącznie, jak i świeckich katolików, w tym żołnierzy niemieckich uczestniczących w Zagładzie europejskich Żydów) z oficjalnym nauczaniem zawartym w Katechizmie Kościoła katolickiego. Widziany w tej perspektywie Niedokończony rozrachunek traci charakter „nienawistnego antykatolickiego pamfletu", a staje się poręcznym narzędziem pozwalającym zdiagnozować stan faktyczny katolickiego stosunku do Żydów. Owszem, można książce zarzucić jednostronność, stronniczość w doborze faktów, brak uwzględniania szerszej perspektywy i pełnego kontekstu drugiej wojny światowej, w której ramach dokonała się Zagłada, nie można jednak odmówić jej autorowi trafności oceny i zasadności wysuwanych z przywołanych faktów wniosków.

Poza tym trzeba przyznać, iż warstwa interpretacyjna w dużej mierze oparta jest na ustaleniach wybitnych teologów katolickich, którzy od lat postulują podobną rein-

${ }^{12}$ M. Czajkowski, Kościót katolicki - organizacja przestępcza?, „Nowe Książki” 2006, nr 10, s. $22-23$. 
terpretację przeszłości Kościoła. Sam Goldhagen nieustannie o tym przypomina: „Wynikające z naszych dociekań wnioski o potrzebie zadośćuczynienia - obejmujące wszystkie aspekty moralnego rozrachunku z przeszłością, w tym zmianę struktur Kościoła, jego praktyk, doktryny i teologii - wynikają nieuchronnie z niepodważalnych na pozór podstawowych zasad, które sam Kościół uznaje za swoje doktrynalne imperatywy. Niektóre z tych wniosków znajdują potwierdzenie również w pracach najwybitniejszych postępowych teologów katolickich i pobożnych katolików piszących o Kościele, jak Hans Kueng, Johann-Baptist Metz, Roger Haight, James Carroll, John Cornwell, Garry Wills i inni. Dla większości z nich punktem wyjścia jest troska o Kościół” (s. 306). Listę teologów od lat postulujących zasadniczą zmianę zarówno nauczania, jak i struktur Kościoła katolickiego można wydłużać w nieskończoność, poczynając zresztą od papieża Jana XXIII, który zwołał Sobór Watykański II i przywrócił do łask wielu teologów odsuniętych od nauczania przez Piusa XII. Podobnie lista „palących problemów czekających na rozwiązanie w Kościele” jest znacznie dłuższa niż ta, którą przedstawia autor Niedokończonego rozrachunku. Była ona układana również po śmierci Jana Pawła II, którego długi pontyfikat tak naprawdę nie zmierzył się z żadnym z tych problemów. Problem więc nie w mnożeniu postulatów reformy, ale w ich realizacji. Sam Goldhagen wielokrotnie podkreśla swój podziw zarówno dla ludzi Kościoła, jak i dla jego doktryny. Jedyne, czego się domaga, to spójność wiary i praktyki życiowej. Czyż można oczekiwać więcej?

Wbrew powtarzanym zarzutom, iż książka Goldhagena jest chaotyczna, pełna powtórzeń i pozbawiona wyrazistej struktury, wydaje się, iż jest właśnie odwrotnie. Mamy tu bowiem do czynienia z niezwykle jasnym zamysłem autorskim realizowanym z żelazną i nader przejrzystą konsekwencją. Trzy główne rozdziały zostały zamknięte rodzajem klamry - „Wprowadzeniem” wyjaśniającym zasadniczy i w gruncie rzeczy dość oczywisty problem (Kościół powinien uznać własne winy wynikłe z jego wiekowego nauczania pogardy dla Żydów i radykalnie zmienić tę tragiczną w skutkach dla Żydów doktrynę) i „Zakończeniem” podpowiadającym równie oczywiste rozwiązania omawianych w książce problemów. Poza postulatem zmiany tekstu Biblii (w samej rzeczy nierealistyczny i absurdalny) inne oczekiwania nie wydają się wcale wyolbrzymione. Zasadnicza treść Niedokończonego rozrachunku została przez autora podzielona na trzy części: Wyjaśnić zachowania (s. 41-106), Osądzić winę (s. 107-188) i Naprawić szkodę (s. 191-310). Fakty i postaci przywoływane w książce Goldhagena są powszechnie znane i wielokrotnie były przedmiotem debaty. Postawa kleru katolickiego popierającego faszystowskie reżimy, konkordat zawarty w 1933 roku z Niemcami po dojściu Hitlera do władzy, zbrodnicza działalność niektórych księży w Chorwacji i na Słowacji, brak zdecydowanej reakcji Piusa XII na postępującą Zagładę Żydów, wreszcie otwarcie procesu beatyfikacyjnego tego papieża połączone z niechęcią do pełnego udostępniania archiwów watykańskich, pomoc niektórych dostojników kościelnych dla zbrodniarzy wojennych po zakończeniu wojny. I tak dalej, i tak dalej. Lista doprawdy przerażająca. Mówił o niej zresztą ostatnio w niezwykle interesującym wywiadzie Stanisław Musiał ${ }^{13}$.

${ }^{13}$ W. Bereś, K. Burnetko, Duchowny niepokorny. Rozmowy z ks. Stanistawem Musiatem, Świat Książki, Warszawa 2006. 
Zasługą Goldhagena jest unaocznienie ich oczywistości i uświadomienie, jak łatwo można by te zaszłości przezwyciężyć. Po prostu uznać fakty i wyciągnąć z nich należyte konsekwencje. Być może to właśnie systematyczne przywoływanie doktryny samego Kościoła, a więc instytucji postawionej w stan oskarżenia, stanowi o porażającej sile jego argumentów?

Powiedziałbym nawet, iż w dużej mierze na naszych oczach są one spełniane niezależnie od żarliwych napomnień Goldhagena. Przecież od czasu ogłoszenia deklaracji soborowej w 1965 roku Nostra aetatae i żydowskiej odpowiedzi w 2000 roku Dabru emet mogłoby się wydawać, że doktrynalny spór mamy za sobą. Czy deklaracja Dominus Iesus z 2000 roku naprawdę stanowi powrót do nauki przedsoborowej? Oczywiście, że nie. Raczej porządkuje nauczanie posoborowe. Tak więc sporo energii zainwestowanej przez autora Niedokończonego rachunku jest zwyczajnie inwestycją chybioną. Wystarczyło poszerzyć nieco listę lektur, by zmniejszyć krytyczny impet.

Niemniej jednak książka zachowuje swoją wartość właśnie jako moralny wstrząs. A jednym z powodów tego wstrząsu jest brak podobnie krytycznych odczytań kościelnej przeszłości w polskiej literaturze przedmiotu. Poza tym brak otwartej konfrontacji z tego rodzaju piśmiennictwem, a nawet lekceważenie i pomijanie krytycznych głosów o Kościele paraliżuje spokojne dochodzenie do prawdy o roli Kościoła w Zagładzie. Sam Kościół i jego obrońcy zbyt pochłonięci są martyrologią katolików, apologią jego przedstawicieli i wskazywaniem na własne dokonania, by mieć czas na równie uważną lekturę krytycznych książek i odmiennych perspektyw badawczych. Dobitnym przykładem tego rodzaju podejścia do historii są coraz liczniejsze procesy beatyfikacyjne i kanonizacyjne. Ich funkcja wychowawcza jest niewątpliwa, wszak winna być uzupełniona równie wnikliwym analizowaniem mniej heroicznych zachowań ludzi Kościoła. Właśnie w tym książka Goldhagena może być pomocna. Jej pomijanie i lekceważenie nie służy prawdzie, o którą Kościół tak bardzo zabiega. A szkoda. Jestem bowiem przekonany, że bomba z opóźnionym zapłonem, jaką skrywa Niedokończony rozrachunek, wybuchnie wcześniej czy później. Oczywiście znacznie bezpieczniejsze byłoby wspólne rozbrojenie ukrytego ładunku. Doświadczenie uczy, iż sam Kościół tego nie robi, zwykle jest przymuszany przez okoliczności zewnętrzne.

Jedną z dróg wyjścia z impasu wskazuje John Hartman, psychiatra z Michigan University od lat zajmujący się rozwiązywaniem konfliktów etnicznych. Razem z polskimi historykami z Przemyśla zaproponował rodzaj wspólnej terapii dla mieszkańców miasta, z którego wywodzą się jego żydowscy przodkowie - wspólną opiekę nad cmentarzem i miejscami kultu. To doświadczenie próbuje zaszczepiać wśród mieszkańców miasteczek pamiętających żydowskich sąsiadów. Na zakończenie chciałbym przywołać ostatni akapit tekstu Hartmana pomieszczonego w książce upamiętniającej przemyskich Żydów: „Kluczem do jakiegokolwiek pojednania pomiędzy Polakami i Żydami jest gotowość uznania cierpień drugiej strony, realistycznego zaakceptowania odpowiedzialności za klęski i niedostatki własnej grupy, oraz wola zaakceptowania i odbycia żałoby po stratach, zarówno materialnych, jak i psychologicznych związanych z wojną. Oznacza to konieczność weryfikacji mentalności opartej na paranoicznej idei wroga. Gdyby tak się stało, zarówno Polacy, jak i Żydzi mogliby nareszcie docenić fakt, 
że dzięki swojemu tysiącletniemu współistnieniu na jednej ziemi zyskali więcej, niż gdyby się nigdy nie spotkali”14.

Można się oczywiście zastanawiać, czy jest to postulat realistyczny, czy można porównywać cierpienia Żydów i Polaków, chrześcijan i żydów, tak jak się zastanawiamy, czy można porównywać cierpienia Niemców i cierpienia Polaków. Można się niepokoić o niepowtarzalność Holokaustu. Ale można też spróbować inaczej, tak jak próbuje John Hartman i jego przemyscy przyjaciele, albo jak to czynił Abraham Joshua Heschel, który nie tyle rozpamiętywał krzywdy swego narodu, ile starał się dostrzec piękno wspólnego zamysłu przemiany świata - tikkun olam.

Być może słabość książki Daniela Goldhagena polega właśnie na tym. Podobnie jak wielu katolików, tak i on nie potrafi dostrzec cierpienia innych. I pewnie dlatego lektura jego książki nie przestaje irytować. Dla mnie jednakże była to irytacja nader pouczająca.

\section{Słowa kluczowe}

Zagłada, Kościół katolicki, Pius XII, antysemityzm, chrześcijańska odpowiedzialność za Zagładę

\section{Key words}

Holocaust, katholic Church, Pius XII, Anti-Semitism, Christian responsibility for the Holocaust

${ }^{14}$ J. Hartman, Stosunku polsko-żydowskie a Holocaust. Spojrzenie psychologiczno-historyczne, w: Pamiętamy każdy dzień... Losy Żydów przemyskich podczas II wojny światowej, Przemyśl 2001, s. 297. 